\title{
Manganese Ions Removal from Industrial Wastewater
}

\author{
EUGENIU VASILE ${ }^{1}$, CRISTINA-ILEANA COVALIU ${ }^{2 *}$, OANA STOIAN $^{2}$, \\ GIGEL PARASCHIV ${ }^{2}$, ECATERINA MATEI ${ }^{3}$, GINA-ALINA CATRINA (TRAISTARU) ${ }^{4}$, \\ ALEXANDRU CIRIC ${ }^{2}$ \\ ${ }^{1}$ University Politehnica of Bucharest, Faculty of Applied Chemistry and Materials Science, 1-7 Gheorghe Polizu Str., \\ Bucharest, Romania \\ ${ }^{2}$ University Politehnica of Bucharest, Faculty of Biotechnical Systems Engineering, 313 Splaiul Independentei, Bucharest, \\ Romania \\ ${ }^{3}$ University Politehnica of Bucharest, Faculty of Materials Science and Engineering, 313 Splaiul Independentei, Bucharest, \\ Romania \\ ${ }^{4}$ National Research and Development Institute for Industrial Ecology - ECOIND, 71-73 Drumul Podu Dambovitei Str., \\ 060652 Bucharest, Romania
}

\begin{abstract}
In this study the removal of Mn (II) ions from wastewater using magnetite nanomaterial was investigated. Some factors influencing the wastewater treatment process were studied such as: treatment time, $\mathrm{pH}$ and the concentration of Mn (II) ions from wastewater. The results showed that using magnetite nanomaterial adsorbent lead to a wastewater treatment efficiency higher than $97 \%$. Langmuir and Freundlich models were applied to describe the adsorption process. The correlation coefficients $\left(R^{2}\right)$ showed that both models are applicable to the experimental data obtained.
\end{abstract}

Keywords: adsorption, magnetite nanomaterial, metals manganese ions, wastewater treatment

\section{Introduction}

The industrial wastewaters polluted with heavy metal ions, which are toxic, is a huge environmental issue [1]. Heavy metals ions affect seriously human health if they are entering in the human body [2-5]. The sources of heavy metal ions pollution are industrial effluents from metal plating and finishing, rubber processing, mining, agriculture and many others [6]. This category of pollutants has toxic actions for our bodies because of their bioaccumulation in the tissues [7-10]. According to the NTPA 001/2002 standard which contains the limits of loading with pollutants of the industrial and domestic wastewater discharged in the natural environment, the concentration of manganese ions should not exceed $1.00 \mathrm{mg} / \mathrm{L}$. Moreover, the limit of $\mathrm{Mn}^{2+}$ accepted in drinking water is $0.05 \mathrm{mg} / \mathrm{L}$ according to the Water Law 458/2002. Nowadays, many methods are used for depollution of industrial wastewater, but some of them are not effective for removing manganese ions or they may be too expensive.

The purpose of this study was to remove low concentrations of manganese ions from wastewaters using the magnetite nanomaterial $\left(\mathrm{Fe}_{3} \mathrm{O}_{4}\right)$. Also, was studied the influence of contact time, $p \mathrm{H}$ and $\mathrm{Mn}$ (II) ions concentration of the wastewater upon the efficiency of the depollution process.

The utilisation of nanosized magnetic oxide particles have many advantages such as: high surface area which gives high capacity of pollutants retaining from wastewater compared with other conventional adsorbents, reduced cost and easily separation from wastewater using magnetic field at the end of the process [11]. For this reason, new methods of depollution implying the use of relatively inexpensive adsorbents are researched (Table 1).

*email: cristina_covaliu@yahoo.com 
Table 1. Manganese ions adsorption from wastewater using different materials

\begin{tabular}{|c|c|c|c|c|c|c|c|c|}
\hline Adsorbent & $\begin{array}{c}\mathrm{Mn}(\mathrm{II}) \text { conc. } \\
(\mathrm{mg} / \mathrm{L})\end{array}$ & $\begin{array}{c}\text { Adsorbent } \\
\text { dosage }(\mathrm{g} / \mathrm{L})\end{array}$ & $\begin{array}{l}\text { Ion solution } \\
(\mathrm{mL})\end{array}$ & $\begin{array}{l}\text { Temp } \\
\left({ }^{\circ} \mathrm{C}\right)\end{array}$ & $\mathrm{pH}$ & $\begin{array}{l}\text { Contact time } \\
(\mathrm{min})\end{array}$ & $\begin{array}{c}\text { Yield } \\
(\%)\end{array}$ & Ref. \\
\hline Activated & 5 & \multirow{4}{*}{$(8,4)$} & \multirow{4}{*}{50} & & \multirow{4}{*}{4} & \multirow{4}{*}{120} & 95.80 & \multirow{4}{*}{12} \\
\hline \multirow{3}{*}{$\begin{array}{l}\text { Carbon Obtained From Birbira } \\
\text { (Militia Ferruginea) Leaves }\end{array}$} & 10 & & & & & & 94.20 & \\
\hline & 20 & & & & & & 92.60 & \\
\hline & 50 & & & & & & 82.80 & \\
\hline \multirow{7}{*}{ RHA } & & \multirow{6}{*}{0.60} & \multirow{7}{*}{100} & \multirow{7}{*}{25} & 2 & - & 36.00 & \multirow{7}{*}{13} \\
\hline & 20 & & & & 5 & - & 78.00 & \\
\hline & & & & & \multirow{5}{*}{6} & 90 & 96.00 & \\
\hline & & & & & & \multirow{4}{*}{60} & 95.00 & \\
\hline & 5 & & & & & & 80.00 & \\
\hline & 40 & & & & & & 55.00 & \\
\hline & 20 & 1.50 & & & & & 95.00 & \\
\hline $\mathrm{CBC}$ & 20 & 0.30 & 100 & 25 & 5.1 & 60 & 75.00 & {$[14]$} \\
\hline PVA/CS & 20 & 8 & 100 & 30 & 5 & 120 & 83.50 & [15] \\
\hline \multirow[t]{4}{*}{ Maize stalks } & \multirow{4}{*}{-} & \multirow{4}{*}{20} & \multirow{4}{*}{25} & - & 1 & \multirow{4}{*}{90} & 16.00 & \multirow{4}{*}[16]{} \\
\hline & & & & - & 7 & & 38.00 & \\
\hline & & & & 25 & - & & 39.00 & \\
\hline & & & & 55 & - & & 13.00 & \\
\hline
\end{tabular}

RHA -Rice husk ash, CBC-Cow bone charcoal, PVA/CS - Polyvinyl alcohol/chitosan

\section{Materials and methods}

\subsection{Materials}

For this study, wastewater solutions having different concentrations $(0.70,1.00,1.20,1.40,1.60$, 1.80 and $2.00 \mathrm{mg} / \mathrm{L}$ ) of $\mathrm{Mn}(\mathrm{II})$ were used. The wastewaters were studied at two different $\mathrm{pH}$ values. The $p \mathrm{H}$ was established by adding sodium hydroxide or hydrogen chloride. The nanomaterial used for this study was magnetite $\left(\mathrm{Fe}_{3} \mathrm{O}_{4}\right)$ and its obtaining method is presented elsewhere [17].

\subsection{Methods}

To remove manganese ions from $100 \mathrm{~mL}$ wastewaters, an amount of $0.2 \mathrm{~g}$ of magnetite was added. These wastewaters were homogenized at room temperature. During the experiments was measured the concentration of Mn(II) ions using a photometer PhotoLab S12.

Adsorption isotherms were used for experimental data modeling.

The removal efficiency ( $\mathrm{n}, \%$ ) and equilibrium adsorption amount $\left(\mathrm{q}_{\mathrm{e}}, \mathrm{mg} / \mathrm{g}\right.$ ) of $\mathrm{Mn}$ (II) ions were calculated using the following formulas:

$$
\eta=\frac{C_{0}-C_{f}}{C_{0}} * 100
$$

where: $\mathrm{C}_{\mathrm{o}^{-}}$represents the initial concentration of $\mathrm{Mn}(\mathrm{II})$ ions, $\mathrm{mg} / \mathrm{L} ; \mathrm{C}_{\mathrm{f}^{-}}$represents the final concentration of $\mathrm{Mn}(\mathrm{II})$ ions, $\mathrm{mg} / \mathrm{L}$.

$$
q_{e}=\frac{\left(C_{0}-C_{f}\right) * V}{W}
$$

where: $\mathrm{C}_{\mathrm{o}^{-}}$represents the initial concentration of $\mathrm{Mn}(\mathrm{II})$ ions, $\mathrm{mg} / \mathrm{L} ; \mathrm{C}_{\mathrm{e}^{-}}$represents the equilibrium concentration of $\mathrm{Mn}(\mathrm{II})$ ions, $\mathrm{mg} / \mathrm{L}$; V - represents the volume of the wastewater, L; W - represents the amount of the magnetite nanomaterial, g.

\section{Results and discussions}

\subsection{Effect of $p H$}

The removal of $\mathrm{Mn}(\mathrm{II})$ ions was studied at two $p \mathrm{H}$ values ( 8 and 11.5), and the results are shown in Figure 1. It can be observed that in the case of the concentration of $0.70 \mathrm{mg} / \mathrm{L}$ the removal efficiency increases with the increase of the $p \mathrm{H}$ from $91.4 \%$ to $92.8 \%$ (Figure 1a). In the case of the 
concentration of $1.00 \mathrm{mg} / \mathrm{L}$ the removal efficiency increases with the increase $p \mathrm{H}$ from $91.0 \%$ to 93.0\% (Figure $1 \mathrm{~b}$ ). For the wastewater having $1.20 \mathrm{mg} / \mathrm{L}$ concentration $\mathrm{Mn}$ (II) the removal efficiency increases with increasing $p \mathrm{H}$ from $90.0 \%$ to $97.5 \%$ (Figure 1c). These observations lead to the conclusion that a basic wastewater is a more favorable medium for the removal of manganese ions from industrial wastewater.

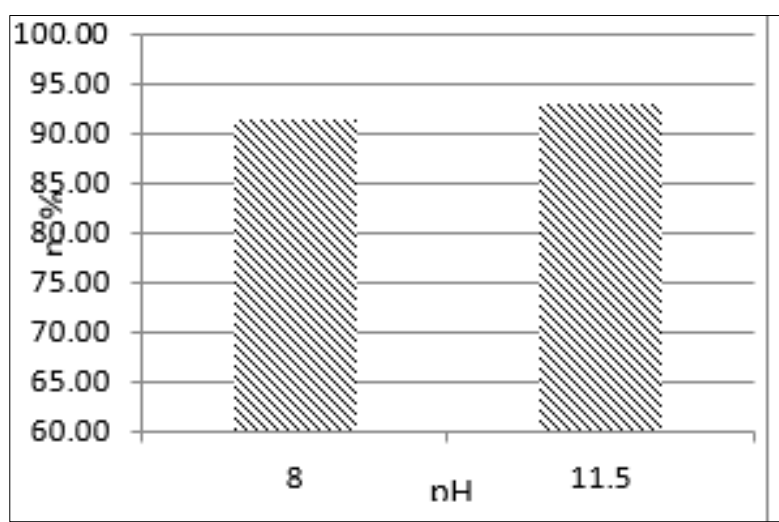

a

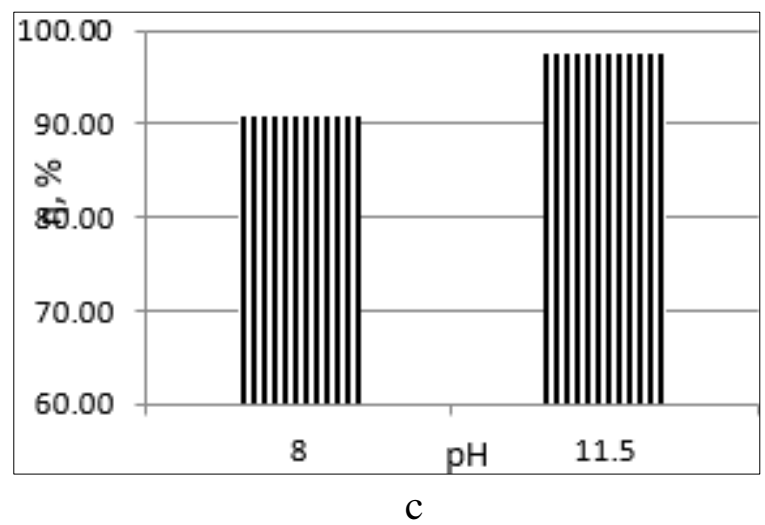

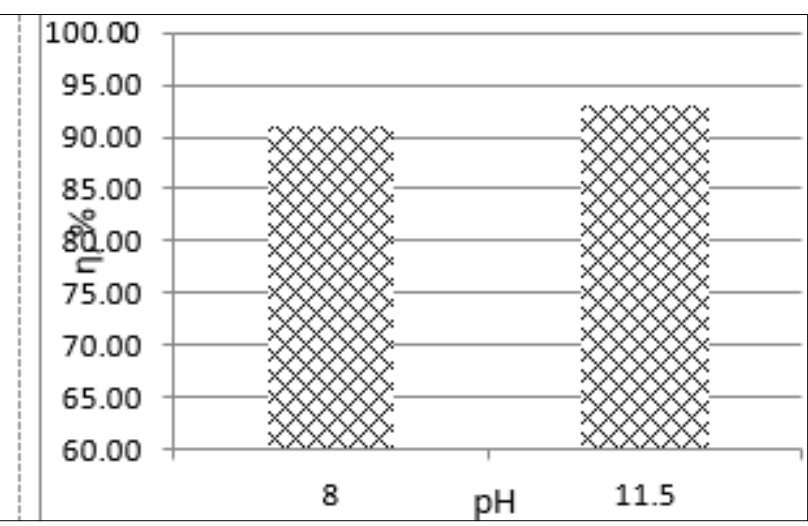

$\mathrm{b}$
Figure 1. Effect of $p \mathrm{H}$ of the wastewater upon the treatment process for three different concentrations of $\mathrm{Mn}^{2+}: 0.70 \mathrm{mg} / \mathrm{L}(\mathrm{a}) ; 1.00 \mathrm{mg} / \mathrm{L}(\mathrm{b})$; 1.20 (c) $\mathrm{mg} / \mathrm{L}$

\subsection{Effect of contact time}

The effect of contact time was studied for the removal of Mn (II) ions from wastewater and the results are shown in Figure 2. It can be seen that the removal efficiency of pollutant removal from wastewater increases with increasing time up to $500 \mathrm{~min}$ after which it remains constant, resulting in a removal efficiency of $90.0 \%$ for $p \mathrm{H} 8$ and $97.5 \%$ for $p \mathrm{H} 11.5$.

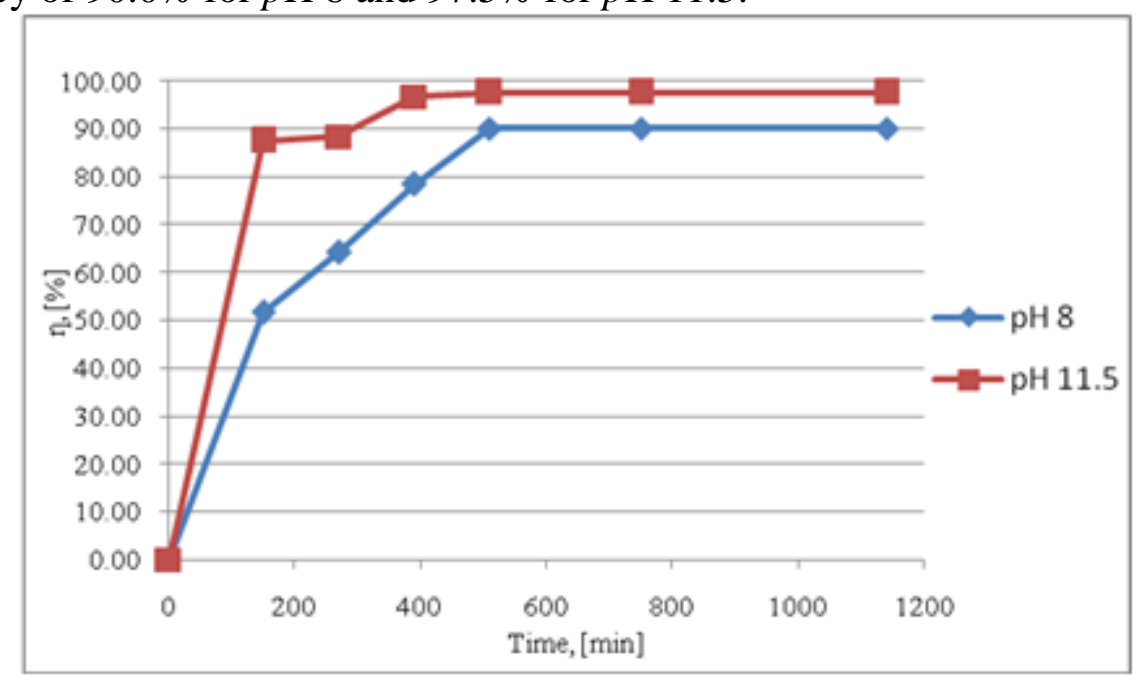

Figure 2. Effect of wastewater treatment time on the removal process of Mn (II) ions (conditions: metal concentration $1.20 \mathrm{mg} / \mathrm{L}$; nanomaterial dosage $0.20 \mathrm{~g} / 100 \mathrm{~mL}$ ) 


\subsection{Adsorption isotherms}

Two models were applied in the study of removal of $\mathrm{Mn}(\mathrm{II})$ ions from wastewater, Langmuir and Freundlich.

\section{Langmuir model}

The Langmuir model is presented in the form of the following equation:

$$
C_{e}=1 / K_{L}-Q_{\max }\left(C_{e} / q_{e}\right)
$$

where: $\mathrm{K}_{\mathrm{L}}$ - is the Langmuir isotherm constant, $\mathrm{L} / \mathrm{mg}$; $\mathrm{Q}_{\max }$ - is the maximum quantity, $\mathrm{mg} / \mathrm{g}$ as the amount corresponding to complete monolayer coverage; $\mathrm{C}_{\mathrm{e}}$ - is the concentration at equilibrium, $\mathrm{mg} / \mathrm{L}$; $\mathrm{q}_{\mathrm{e}}$ - is the amount of metal adsorbed per gram of the adsorbent at equilibrium, $\mathrm{mg} / \mathrm{g}$.

Using the following equation was calculated the equilibrium parameter $\mathrm{R}_{\mathrm{L}}$ :

$$
R_{L}=\frac{1}{1+K_{L} * C_{0}}
$$

where: $R_{L}$ - value indicates that the process is unfavourable if $R_{L}>1$, linear if $R_{L}=1$, favourable if $0<$ $\mathrm{R}_{\mathrm{L}}<1$ and irreversible if $\mathrm{R}_{\mathrm{L}}=0 ; \mathrm{K}_{\mathrm{L}}$ is the Langmuir constant; $\mathrm{C}_{0}$ - is the initial concentration, measured in $\mathrm{mg} / \mathrm{L}$.

\section{Freundlich model}

Freundlich model is presented as the equation:

$$
q_{e}=K_{F} * C_{e}{ }^{1 / n}
$$

where: $\mathrm{q}_{\mathrm{e}}$ - is the quantity of metal adsorbed by adsorbent at equilibrium, $\mathrm{mg} / \mathrm{g} ; \mathrm{K}_{\mathrm{F}}$ - is the Freundlich isotherm constant, $\mathrm{mg} / \mathrm{g} ; \mathrm{C}_{\mathrm{e}}$ - is the equilibrium concentration of adsorbate, $\mathrm{mg} / \mathrm{L} ; \mathrm{n}-$ is the adsorption intensity;

The Langmuir and Freundlich models based on experimental data were graphically represented (Figure 3,4). The constants of both models are presented in Table 2. It is observed that the experimental values fit the isotherms adequately. In the case of the Langmuir model, its applicability indicates the monolayer coating of the magnetite surface by the manganese ions. The Langmuir constant $R_{L}$ is in the range $0-1$, indicating that the retention process of $\mathrm{Mn}$ (II) ions is favorable. The linear graph between $\log \left(\mathrm{C}_{\mathrm{e}}\right)$ and $\log \left(\mathrm{Q}_{\mathrm{e}}\right)$ confirm the applicability of the Freundlich model.

Table 2.The constants of Langmuir and

Freundlich models

\begin{tabular}{ccccccc}
\hline & \multicolumn{3}{c}{ Langmuir isotherm } & \multicolumn{3}{c}{ Freundlich isotherm } \\
\hline Adsorbent & $\mathrm{K}_{\mathrm{L}}(\mathrm{L} / \mathrm{mg})$ & $\mathrm{R}_{\mathrm{L}}$ & $\mathrm{R}^{2}$ & $\mathrm{n}$ & $\mathrm{K}_{\mathrm{F}}(\mathrm{mg} / \mathrm{g})$ & $\mathrm{R}^{2}$ \\
\hline $\mathrm{Fe}_{3} \mathrm{O}_{4}$ & 6.58 & 0.71 & 0.88 & 0.93 & 3.15 & 0.98 \\
\hline
\end{tabular}

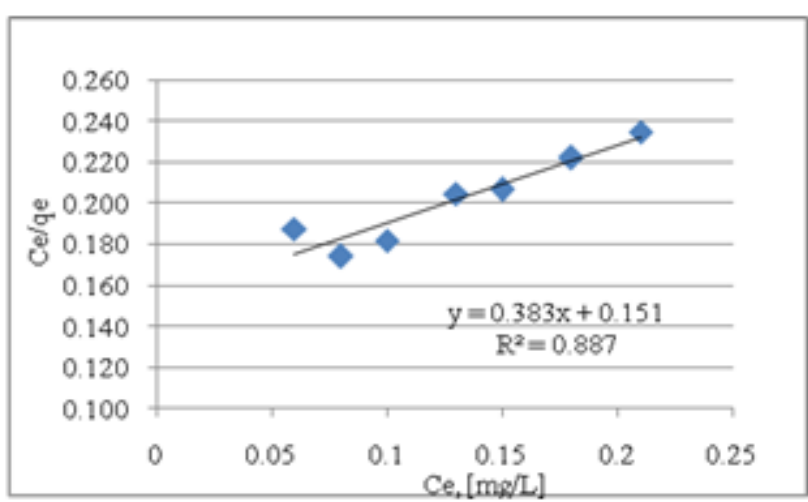

Figure 3. The plot of the Langmuir model

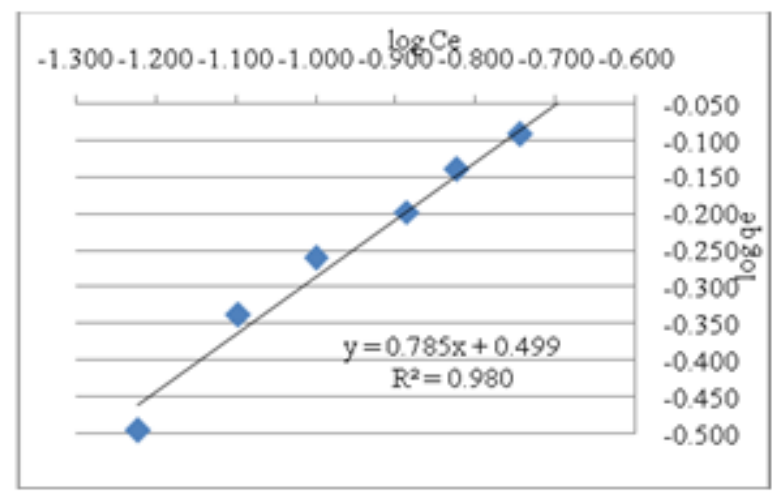

Figure 4. The plot of the Freundlich model 
The results suggest that this type of magnetic nanomaterial could be successfully used for manganese ions removal from industrial wastewaters. The possibility of fast separation by magnetic field of magnetite from the wastewater at the end of the treatment and the high removal efficiency recommend it as a useful adsorbent. Also, future regeneration studies will be undertaken in order to establish the life duration use of the magnetite adsorbent. It is a very high probability that the magnetite nanomaterial can be adapted to the removal of other types of heavy metals from wastewater.

\section{Conclusions}

The study focused on the removal of manganese ions from wastewater. The removal of $\mathrm{Mn}$ (II) ions from wastewater using $\mathrm{Fe}_{3} \mathrm{O}_{4}$ nanomaterial reveal that the process was $p \mathrm{H}$ dependent and the maximum efficiency was observed at $p \mathrm{H} 11.5$ resulting in a yield of 97.50\%. At a lower $p \mathrm{H}(8)$ the maximum depollution efficiency was $91.00 \%$. The treatment time required to reach the maximum capacity of the magnetite nanomaterial in order to remove the $\mathrm{Mn}$ (II) ions was $500 \mathrm{~min}$, then the $\mathrm{Mn}$ (II) ions concentrations remained constant in the wastewaters. The $\mathrm{R}^{2}$ values indicate that adsorption process take place onto heterogeneous material, according to Freundlich model. Values of $\mathrm{n}$ lower than 1 indicates possible binding between magnetite and manganese ions.

Aknowledgement: This work was supported by a grant of the Romanian Ministry of Research and Innovation, CCCDI-UEFISCDI, project number 26PCCDI/01.03.2018, "Integrated and sustainable processes for environmental clean-up, wastewater reuse and waste valorization" (SUSTENVPRO), within PNCDI III.

\section{References}

1. CIMINO, G., PASSERINI, A., TOSCANO, G., Removal of toxic cations and Cr(VI) from aqueous solutions by hazelnut shell, Water. Res., 34(11), 2000, 2955-2962.

2.SUANTAK K., BIPIN S., Optimization of Process Parameters using Response Surface Methodology (RSM): Removal of Cr (VI) from Aqueous Solution by Wood Apple Shell Activated Carbon (WASAC),

Res.J.Chem.Sci., 3(7), 2013, 31-37.

3.PASCU D.E., PASCU (NEAGU) M., TRAISTARU G.A., NECHIFOR A.C., ALEXANDRA RALUCA MIRON A.R., Iron and manganese removal from drinking water, J. Electrochem. Sci. Technol., 6(1), 2016, 47-55.

4.JOHN, M. K., LAERHOVEN, V., CROSS, C. H., Cadmium, Lead and Zinc accumulate in soils nearer a smother complex, Environ. Lett., 10,1975, 25-35.

5.TILLER, K.Y., Heavy metals in soil and their environmental significance, Adv.Soil.Sci., 9, 113-142. 6.SOUTHICHAK, B., NAKANO, K., NOMURA, M., CHIBA, N., NISHMURA, O., Phragmite austrilis: a novel biosorbent for the removal of heavy metals from aqueous solutions, Water Res., 40, 2006, 295-2302.

7.BUMBAC C., MANEA E.E., TIRON O., BADESCU V., Correlation Between Wastewater Treatment Performances and Sludge Characteristics, Rev. Chim, 69(1), 2018, 10-13.

8. TRAiSTARU G.A., COVALIU I.C., GALliOS G.P., CURSARU D.L., JITARU I., Removal of Nitrate from Water by Two Types of Sorbents Characterization and sorption studies, Rev. Chim., 3(63), 2012, 268-271.

9.KIM L., VASILE G. G., STANESCU B., DINU C., ENE C., Distribution of Trace Metals in Surface Water and Streambed Sediments in the Vicinity of an Abandoned Gold Mine from Hunedoara County, Romania, Rev.Chim., 8(67), 2016, 1441 - 1446.

10.CUCIUREANU, A., KIM, L., LEHR, C.B., ENE, C., The Groundwater Quality of the Area Tailings Mining Ponds in the North of Romania, Rev. Chim., 68(8), 2017, 1695-1699.

11.PETROVA T. M., FACHIKOV L., HRISTOV J., The Magnetite as Adsorbent for Some Hazardous Species from Aqueous Solutions: a Review, I.RE.CH.E., 3(2), 2011, 134-152. 
12. EMMANUEL, K.A., VEERABHADRA RAO, A., Adsorption of Mn (II) from aqueous solutions using pithacelobium dulce carbon, Rasayan J. Chem., 1(4), 2008, 840-852.

13. MENGISTIE, A. A., SIVA RAO, T., PRASADA RAO, A. V., Adsorption of Mn(II) Ions From Wastewater Using Activated Carbon Obtained From Birbira (Militia Ferruginea) Leaves, GJSFR,

12 (1), 2012, 1-12.

14. ZHANG, Y., ZHAO, J., JIANG, Z., SHAN, D., LU, Y., Biosorption of Fe(II) and Mn(II) Ions from Aqueous Solution by Rice Husk Ash, Biomed Res. Int., 2014, 1-10.

15. MORENO, J. C., GÓMEZ, R., GIRALDO, L., Removal of $\mathrm{Mn}, \mathrm{Fe}, \mathrm{Ni}$ and $\mathrm{Cu}$ Ions from Wastewater Using Cow Bone Charcoal, Materials, 3, 2010, 452-466.

16. ABDEEN, Z., MOHAMMAD, S.G., MAHMOUD, M.S., Adsorption of Mn (II) ion on polyvinyl alcohol/chitosan dry blending from aqueous solution, Environ. Nanotechnol. Monit. Manag., 3, 2015, $1-9$.

17. EL-SAYED G.O., DESSOUKI, H. A., IBRAHIEM, S. S., Removal of Zn(II), Cd(II) and Mn(II) from aqueous solutions by adsorption on maize stalks, MJAS, 15(1), 2011, $8-21$.

18. COVALIU, I. C., NEAMTU, J., GEORGESCU, G., MALAERU, T., CRISTEA, C., JITARU, I., Synthesis and characterization of ferrites $\left(\mathrm{Fe}_{3} \mathrm{O}_{4} / \mathrm{CuFe}_{2} \mathrm{O}_{4}\right)$ - calcium alginate hybrids for magnetic resonance imaging, Dig. J. Nanomater. Bios., 6(1), 2011, $245-252$.

Manuscript received: 10.02 .2020 